\title{
MEREDUKSI STRES DALAM BELAJAR DENGAN MENGGUNAKAN STRATEGI RELAKSASI
}

\author{
Ita Dian Arvita Sari \\ SMA Negeri 1 Mantup \\ itadianarvitasari@gmail.com
}

\begin{abstract}
During the Covid-19 pandemic, everything must be done from home, including studying. There are many problems faced by students during Distance Learning (PJJ), which ultimately makes students experience stress in learning. Starting from students feeling bored studying at home, having difficulty concentrating, being anxious, restless when getting assignments from the teacher, causing dizziness / headaches and reduced appetite. The problems above, if not resolved immediately, will have an impact on the value of student learning outcomes. One of the strategies to overcome this problem is relaxation strategy. The purpose of this study was to determine that relaxation techniques can reduce stress in class XI MIPA 1 students of SMA Negeri 1 Mantup Lamongan, teaching 2020/2021. This research is a single subject research. This research lasted for 2 cycles, namely cycle I and cycle II. Data collection techniques using interviews, observation, and measurement scale questionnaires. Methods of data analysis using qualitative and quantitative data analysis. The initial condition of the stress score reached 87.5 , cycle I 75 , while cycle II 47.5. From the results of the analysis, it can be concluded that there are differences in the stress levels of student learning before and after the action. Thus it can be concluded that relaxation strategies can reduce stress in learning for class XI MIPA 1 SMA Negeri 1 Mantup academic year 2020/2021.
\end{abstract}

\section{ABSTRAK}

Di masa pandemi Covid-19 ini di mana segala sesuatu harus dilakukan dari rumah, termasuk belajar. Banyak permasalahan yang dihadapi siswa selama Pembelajaran Jarak Jauh (PJJ), yang akhirnya membuat siswa mengalami stres dalam belajar. Mulai dari siswa merasa jenuh belajar di rumah, sulit berkonsentrasi, cemas, gelisah ketika mendapat tugas dari guru, sehingga menimbulkan pusing/sakit kepala dan nafsu makan berkurang. Permasalahan di atas jika tidak segera diselesaikan maka akan berdampak pada nilai hasil belajar siswa. Salah satu strategi untuk mengatasinya yaitu dengan strategi relaksasi. Tujuan dari penelitian ini adalah untuk mengetahui teknik relaksasi dapat mereduksi stres dalam siswa kelas XI MIPA 1 SMA Negeri 1 Mantup Lamongan ajaran 2020/2021. Penelitian ini merupakan penelitian single subject. Penelitian ini berlangsung selama 2 siklus yaitu siklus I dan siklus II. Teknik pengumpulan data menggunakan wawancara, observasi, dan angket skala pengukuran. Metode analisis data menggunakan analisis data kualitatif dan kuantitatif. Kondisi awal skor stres mencapai 87,5, siklus I 75 sedangkan siklus I| 47,5. Dari hasil analisis dapat disimpulkan bahwa ada perbedaan tingkat stres belajar siswa sebelum dan sesudah tindakan. Dengan demikian dapat disimpulkan bahwa strategi relaksasi dapat mereduksi stres dalam belajar siswa kelas XI MIPA 1 SMA Negeri 1 Mantup tahun ajaran 2020/2021.

Kata Kunci

Stres dalam belajar, relaksasi 
Cara mengutip: Sari, I. D. A. (2020). Mereduksi Stres Dalam Belajar Dengan Menggunakan Strategi Relaksasi. Nusantara of Research : Jurnal Hasil-Hasil Penelitian Universitas Nusantara PGRI Kediri (eJournal), 7(2), 79-85. https://doi.org/10.29407/nor.v7i2.15057

\section{PENDAHULUAN}

Di masa pandemi Covid-19 ini di mana segala sesuatu harus dilakukan dari rumah, termasuk belajar. Berbagai permasalahan muncul selama diberlakukannya Pembelajaran Jarak Jauh (PJJ), mulai dari jaringan hingga sarana prasarana pendukung proses belajar di rumah. Selain itu siswa mulai merasa jenuh belajar di rumah, sulit berkonsentrasi, cemas, gelisah ketika mendapat tugas dari guru, sehingga menimbulkan pusing/sakit kepala dan nafsu makan berkurang. Hal ini terjadi pada ELA (Inisial) siswa kelas XI MIPA 1. Berdasarkan presensi siswa jarang mengikuti PJJ, siswa juga jarang mengumpulkan tugas dari guru. Stres belajar adalah suatu respon psikologis, fisik, pikiran, dan perilaku yang dialami oleh siswa ketika mendapat tekanan-tekanan dan ketidak nyamanan saat belajar. Tekanan-tekanan yang dimaksud tekanan yang berhubungan dengan belajar dan kegiatan sekolah, misalnya saya deadline tugas atau PR, memforsir belajar mempersiapkan ujian, dan hal-hal yang lain yang berkaitan dengan belajar

Permasalahan di atas jika tidak segera diselesaikan maka akan berdampak pada nilai hasil belajar siswa. Selain itu jika stres belajar menumpuk dan tidak tertangani akan berdampak pada tubuh yang sakit-sakitan, sakit kepala, bingung (Aryani, 2016). Jika stress belajar dapat tertangani implikasinya siswa menjadi lebih bersemangat dalam belajar sehingga nilai belajar siswa pun akan meningkat. Kejadian di atas harus segera direduksi dengan suatu model relaksasi. Relaksasi merupakan strategi sederhana dan mudah diaplikasikan untuk merekduksi stress belajar (Nurdini, 2009). Salah satu penyebab timbulnya stress belajar ialah kecapean atau lelah, tumpukan tugas yang sulit dipahami, kurang waktu istirahat serta kecemasan berebihan ketika mendapatkan tugas dari guru. Kecemasan timbul karena ketidaksiapan siswa baik secara fisik atau mental dalam belajar, apalagi pada masa pandemik ini, oleh karena itu diharapkan relaksasi mampu mereduksi stress belajar. Menurut Burn dalam Subandi (2003) manfaat dari strategi relaksasi adalah individu lebih mampu menghindari reaksi yang berlebihlebihan karena adanya stress. Penelitian sebelumnya yang dilakukan oleh Bambang Agus Pramunto (2016) dengan judul Strategi Relaksasi Untuk Membantu Siswa Yang Mengalami Stres Belajar Di Kelas 9D SMP Negeri 1 Mejayan Kabupaten Madiun, hasilnya Strategi Relaksasi dapat membantu siswa yang mengalami stres belajar di Kelas 9D SMPN 1 Mejayan Kabupaten Madiun.

Strategi relaksasi merupakan proses mengurangi efek stres pada pikiran dan tubuh. Relaksasi mudah diaplikasikan pada kegiatan sehari-hari. Menurut Suyono (2016) dalam jurnal Relaksasi bermanfaat untuk menurunkan detak jantung, tekanan darah, laju pernapasan, dan ketegangan otot. Ketegangan merupakan keadaan kekakuan fisik pada tubuh yang dapat menimbulkan rasa sakit bahkan reaksi emosional seperti kecemasan. Relaksasi fisik bertujuan untuk menghilangkan ketegangan ini dan mengendurkan otot dan kelompok otot secara progresif. Relaksasi psikologis terjadi ketika pikiran relatif bebas dari stres dan gangguan. 
Berdasarkan permasalahan di atas, dapat dirumuskan permasalahan sebagai berikut: "Apakah stategi relaksasi dapat mereduksi stres dalam belajar siswa kelas XI MIPA 1 SMA Negeri 1 Mantup Lamongan tahun ajaran 2020/2021?". Tujuan dari penelitian ini adalah untuk mengetahui strategi relaksasi dapat mereduksi stres dalam siswa kelas XI MIPA 1 SMA Negeri 1 Mantup Lamongan ajaran 2020/2021.

\section{METODE}

Penelitian ini merupakan penelitian tindakan bimbingan dan konseling. Alur kerja penelitian tindakan menurut Kemmis dan Mc. Taggart dalam Arikunto (2006:97), alur penelitian itu terdiri dari empat kegiatan pokok, yaitu perencanaan (planning), tindakan (action) dan observasi (observe), serta refleksi (reflect). Penelitian ini dilaksanakan di SMAN 1 Mantup Lamongan, dengan menggunakan single subject yaitu siswa kelas XI MIPA 1 SMAN 1 Mantup yang memiliki tingkat stres dalam belajar tinggi.

Penelitian ini dilakukan dalam 2 siklus dan masing-masing siklus dilaksanakan dalam 4 tahap yaitu tahap perencanaan, pelaksanaaan, pengamatan (observasi) dan refleksi:1) Perencanaan, Pada tahap ini langkah-langkahnya sebagai berikut: a) Menyusun RPLBK, b) Menyiapkan media layanan, c) Menyiapkan LKPD, d) Menyiapkan evaluasi (proses dan hasil); 2) Pelaksanaan, pelaksanaan dibagi menjadi 4 tahap yaitu tahap awal, tahap transisi, tahap inti, dan tahap penutup; 3) Observasi (Pengamatan), Observasi yang dilakukan disini ialah melakukan pengamatan secara langsung dan mencatan kekurangan serta kekurangan dari hasil pelayanan yang diberikan konselor. Hasil dari observasi dijadikan sebagai pijakan untuk refleksi dalam Menyusun siklus berikutnya; 4) Refleksi, Refleksi proses dimana peneliti menganalisa hasil dari observasi, apa yang menyebabkan proses konseling berhasil pada siklus 1 dan apa pula kekurangan pada siklus 1 . Hasil dari refleksi dijadikan pijakan untuk siklus selanjutnya.

Menurut Sukardi dalam Arikunto (2003), bahwa pada dasarnya dalam penelitian tindakan kelas data yang dikumpulkan dapat dibedakan menjadi 2 (dua) jenis data yaitu: (1) Data kuantitatif, yang mana dalam menganalisa dengan analisis statistik deskriptf. dan (2) Data kualitatif, data yang berbentuk kalimat yang memberi gambaran tentang ekspresi siswa terhadap tingkat pemahaman terhadap suatu mata pelajaran (kognitif), pandangan atau sikap siswa terhadap metode belajar yang baru (afektif), aktivitas siswa dalam mengikuti pelajaran, motivasi belajar, dan sejenisnya. Penelitian ini menggunakan teknik analisis data kualitatif deskriptif yang didukung oleh analisis data kuantitatif.

\section{HASIL}

\section{Deskripsi Tahap Studi Awal}

Layanan konseling individu dengan strategi relaksasi akan diberikan kepada Ananda ELA (inisial) kelas XI MIPA 1. Pemberian layanan konseling individu, disini peneliti menjelaskan prosedur yang harus diikuti oleh siswa. Diharapkan agar siswa dapat mengikuti prosedur layanan konseling individu mulai dari tahap awal sampai penutup. Peneliti juga berkolaborasi dengan teman sejawat sebagai observer dalam kegiatan layanan yang dilakukan. Yang hasilnya digunakan sebagai bahan pertimbangan perbaikan pemberian layanan konseling 
individu berikutnya. Sebelum melakukan konseling, konselor memberikan angket skala pengukuran yang terdiri dari beberapa item pertanyaan untuk mengetahui tingkat stres dalam belajar siswa. Pada kondisi awal skor stres dalam belajar siswa mencapai 87,5 atau dalam kategori tinggi.

\section{Pelaksanaan Penelitian Siklus I}

\section{Perencanaan}

Untuk mengoptimalkan pelaksanaan layanan, maka disusun perencanaan sebagai berikut: 1) Menyusun RPLBK; 2) Menyiapkan media layanan; 3) Menyiapkan LKPD; 4) Menyiapkan evaluasi (proses dan hasil); 5) Menyusun skala pengukuran.

\section{Pelaksanaan}

Siklus I dilaksanakan dilakukan secara daring melalui aplikasi zoom meeting selama 30 menit. Yang dilakukan pada pukul 12.30-13.00. Untuk melakukan konseling individu. Kegiatan layanan konseling individu terbagi dalam tahap awal, transisi, inti, dan penutup. Pada siklus I kegiatan layanan berjalan kurang lancar karena terkendala jaringan sehingga siswa kurang mendengar instruksi dari guru.

\section{Observasi (Pengamatan)}

Berdasarkan hasil observasi secara keseluruhan pelaksanaan layanan konseling individu dengan menggunakan strategi relaksasi diperoleh catatan bahwa pada siklus I kegiatan layanan berjalan kurang lancar karena sempat terputus karena terkendala jaringan pada proses layanan, siswa terlibat aktif dalam kegiatan layanan, siswa juga antusias menerapkan strategi relaksasi akan tetapi siswa kurang mendengar instruksi dari guru. Hal ini mengakibatkan hasil yang diperoleh kurang maksimal di mana siswa masih merasakan ada bagian-bagian tubuh yang kurang relaks. 1) Observasi Pelaksanaan Tindakan, Dari hasil observasi yang dilakukan oleh teman sejawat, dalam proses pelaksanaan layanan konseling masih ada yang perlu diperbaiki. Dalam proses penggalian masalah masih kurang dalam; 2) Hasil Pemberian Tindakan, Untuk melihat ada tidaknya perubahan stres dalam belajar, peneliti memberikan angket skala pengukuran terhadap siswa yang menjadi subjek penelitian. Setelah dilakukan relaksasi tingkat stres dalam belajar siswa turun, dari skor 87,5 (tinggi) turun menjadi 75 (sedang). Dari hasil skala pengukuran menunjukkan penurunan tingkat stress dalam belajar siswa tetapi belum menunjukkan penurunan yang signifikan. Sehingga belum mencapai hasil yang diharapkan. Untuk itu perlu dilanjutkan ke kegiatan siklus II.

\section{Refleksi}

Refleksi merupakan kegiatan pasca pemberian Tindakan. Tujuan refleksi disini ialah untuk mengetahui sejauh mana tingkat keberhasilan pelayanan yang telah diberikan oleh konselor. Kegiatan refleksi dilaksanakan di ruang BK dihadiri oleh peneliti dan teman sejawat. Hasil yang didapat ialah sebagai berikut. 1) Aktivitas konselor dalam pelaksanaan konseling individu dapat dikategorikan baik; 2) Hasil angket skala pengukuran terhadap stres dalam belajar siswa, berdasarkan data hasil pengolahan menunjukkan pemberian tindakan pada siklus I mampu mereduksi tingkat stres dalam belajar siswa mencapai angka 75 atau dalam kategori sedang. 
Kondisi awal tingkat stres dalam belajar siswa mencapai 87,5 atau masuk dalam kategori tinggi, setelah tindakan turun menjadi 75 atau dalam kategori sedang. Hasil yang diperoleh siswa menunjukkan penurunan stres belajar hanya saja kurang signifikan. Agar hasil yang diperoleh lebih maksimal dan stres belajar siswa menunjukkan penurunan yang signifikan maka akan direncanakan siklus II, yang dilakukan secara daring dan dengan menggunakan langkah-langkah relaksasi yang lebih lengkap. Dan dipandu langsung oleh konselor. Diharapkan siswa dapat memecahkan masalahnya dengan ditandai penurunan tingkat stres yang signifikan.

\section{Pelaksanaan Penelitian Siklus II \\ Perencanaan}

Perencanaan pelaksanaan penelitian tindakan bimbingan dan konseling pada siklus II mengacu pada hasil pelaksanaan layanan siklus I. Beberapa kegiatan yang termuat dalam tahap perencanaan meliputi: 1) Menyusun RPLBK; 2) Menyiapkan media layanan; 3) Menyiapkan LKPD; 4) Menyusun pedoman observasi atau pengamatan; 5) Menyusun skala pengukuran. Digunakan untuk mengumpulkan data dari siswa mengenai perubahan yang terjadi setelah pemberian konseling individu pada siklus II; 6) Pemberian layanan konseling individu pada siklus II ini peneliti menggunakan langkah-langkah relaksasi yang telah direvisi berbeda dari siklus I.

\section{Pelaksanaan}

Siklus II dilaksanakan dilakukan secara daring melalui aplikasi zoom meeting selama 30 menit. Yang dilakukan pada pukul 11.30-12.00. Untuk melakukan konseling individu. Pada siklus II kegiatan layanan berjalan lancar, siswa terlibat aktif dalam kegiatan layanan, siswa juga antusias menerapkan strategi relaksasi. Jaringan juga mendukung, sehingga suara konselor dapat terdengar jelas oleh siswa. Selain itu siswa juga lebih memahami instruksi dari konselor, sehingga hasilnya dapat lebih maksimal Hasil angket skala pengukuran siklus II siswa mendapatkan skor 47,5 yang artinya masuk dalam kategori stres rendah. Kegiatan layanan konseling individu terbagi dalam tahap awal, transisi, inti, dan penutup.

\section{Observasi}

Hasil pengamatan teman sejawat terhadap pelaksanaan tindakan bimbingan konseling. Dalam pertemuan ini aktivitas konselor mengalami peningkatan dari kategori baik menjadi sangat baik. Dan pada pertemuan ini adanya kepuasan baik konselor maupun konseli. Berdasarkan hasil observasi secara keseluruhan pelaksanaan layanan konseling individu dengan menggunakan strategi relaksasi diperoleh catatan bahwa pada siklus II kegiatan layanan berjalan lancar, siswa terlibat aktif dalam kegiatan layanan, siswa juga antusias menerapkan strategi relaksasi. Jaringan juga mendukung, sehingga suara konselor dapat terdengar jelas oleh siswa. Selain itu siswa juga lebih memahami instruksi dari konselor, sehingga hasilnya dapat lebih maksimal. Pada siklus II ini terjadi penurunan tingkat stres dalam belajar siswa dari 75 (sedang) menjadi 47,5 (rendah). Dampak positif pemberian tindakan melalui penerapan konseling individu dengan menggunakan strategi relaksasi dapat mereduksi stres dalam belajar siswa. 


\section{Refleksi}

Kegiatan refleksi siklus II dilaksanakan di ruang bimbingan dan konseling SMAN 1 Mantup dan dihadiri peneliti dan teman sejawat. Setelah mencermati, mengkaji dan menganalisis data yang ada, maka hasilnya dapat diuraikan sebagai berikut: 1) Aktivitas guru BK/konselor dan siswa secara umum mencapai kategori sangat baik, dan adanya pemahaman yang tinggi dengan menurunnya tingkat stres dalam belajar siswa dan adanya rasa puas baik siswa maupun guru; 2) Pelaksanaan tindakan melalui konseling individu telah membawa perubahan yang positif dengan menurunnya tingkat stres dalam belajar siswa. Data penelitian siklus II tingkat stres dalam belajar siswa turun mencapai skor 47,5 atau dalam kategori rendah. Hasil yang diperoleh siswa menunjukkan penurunan stres belajar yang lebih signifikan dibanding siklus I. Hal ini menunjukkan bahwa permasalahan siswa dapat terpecahkan dengan ditandai penurunan tingkat stres yang signifikan. Oleh karena itu penelitian tindakan bimbingan dan konseling dalam upaya mereduksi stres belajar siswa dianggap cukup dan tidak perlu dilanjutkan ke siklus berikutnya. Berdasarkan siklus | dan siklus || yang telah dilakukan diperoleh data kuantitatif sebagai berikut:

Tabel 1. Tingkat Stree Dalam Belajar Siswa Dalam Siklus PTBK

\begin{tabular}{lll}
\hline Keterangan & Skor & Kategori \\
\hline Kondisi Awal & 87,5 & Tinggi \\
Siklus I & 75 & Sedang \\
Siklus II & 47,5 & Rendah \\
\hline
\end{tabular}

Dari tabel di atas dapat dibuat grafik sebagai berikut:

\section{Tingkat Stres Dalam Belajar Siswa}

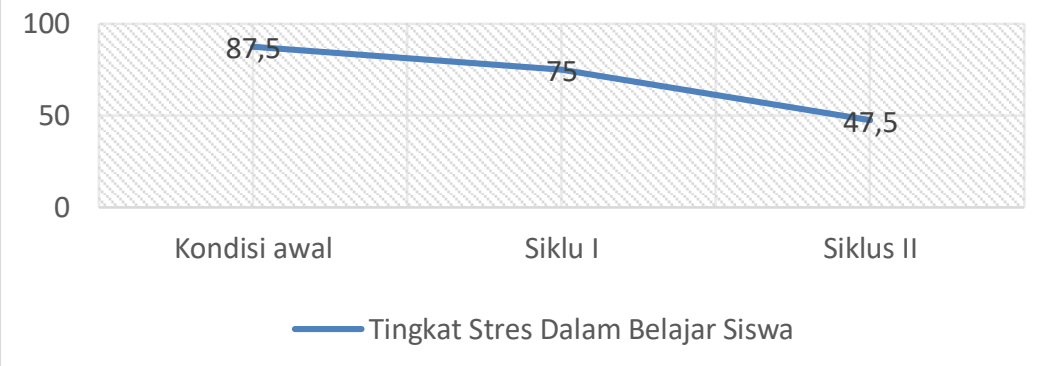

Gambar 1. Grafik Tingkat Stree Dalam Belajar Siswa Dalam Siklus PTBK

Dari tabel di atas menunjukkan bahwa skor awal siswa sebesar 87,5 masuk dalam kategori tinggi, pada siklus I setelah dilakukan tindakan skor stres belajar siswa menurun menjadi 75 masuk dalam kategori sedang, sedangkan pada siklus II setelah dilakukan tindakan skor stres belajar siswa menurun menjadi 47,5 masuk dalam kategori rendah.

\section{PEMBAHASAN}

Berdasarkan hasil penelitian, dapat diartikan bahwa strategi relaksasi dapat dijadikan alternatif bantuan bagi siswa yang mengalami stres belajar. Hal ini sesuai dengan pendapat Frogatt (2006), dengan pelatihan relaksasi akan membantu dalam melakukan banyak hal, misalnya mengendalikan stres, kecemasan, mengurangi rasa sakit, mengatasi prosedur medis, menurunkan tekanan darah, dan mempermudah tidur. Penelitian Tindakan Bimbingan dan Konseling dilaksanakan dalam 2 siklus, untuk mengetahui apakah strategi relaksasi dapat mereduksi stres belajar siswa. Sebelum pelaksanaan siklus I peneliti melaksanakan kegiatan 
pra penelitian untuk mengetahui kondisi awal siswa. Kondisi awal siswa skor stres belajar siswa sebesar 87,5 masuk dalam kategori stres belajar tinggi, pada siklus I setelah siswa diberikan tindakan skor stres belajar siswa menurun menjadi 75 masuk dalam kategori stres belajar sedang, sedangkan pada siklus II setelah siswa diberikan tindakan skor stres belajar siswa menurun menjadi 47,5. Dari data tersebut menunjukkan adanya perbedaan tingkat stres belajar siswa sehingga dapat disimpulkan bahwa strategi relaksasi dapat mereduksi stres belajar siswa. Hal ini diperkuat dari hasil penelitian terdahulu yang dilakukan Suyono, Suyono, Triyono, Dany M. Handarini (2016) dijelaskan bahwa teknik relaksasi efektif untuk menurunkan stres akademik siswa SMA.

\section{KESIMPULAN DAN SARAN}

Dari hasil analisis dapat disimpulkan bahwa ada perbedaan tingkat stres belajar siswa sebelum dan sesudah tindakan. Hal ini dapat dilihat dari skor stres dalam belajar siswa dimana pada kondisi awal skor stres belajar siswa sebesar 87,5 (tinggi), menjadi 75 (sedang) pada siklus I. Kemudian pada siklus II menurun menjadi 47,5 (rendah). Dengan demikian dapat disimpulkan bahwa strategi relaksasi dapat mereduksi stres dalam belajar siswa kelas XI MIPA 1 SMA Negeri 1 Mantup tahun ajaran 2020/2021.

Berdasarkan pelaksanakan penelitian Tindakan yang dilakukan, ada beberapa saran yang yang akan peneliti kemukakan: 1) Agar penyelenggaran program bimbingan dan konseling mencapai hasil yang optimal dibutuhkan inovasi dan improvisasi secara terus menerus sesuai dengan kebutuhan dan perkembangan jaman; 2) Dalam melaksanakan kegiatan layanan bimbingan konseling hendaknya guru pembimbing mengetahui karakteristik kebutuhan siswa, tahapan-tahapan layanan konseling, konsep awal siswa, serta alat atau media yang digunakan sesuai dengan kebutuhan; 3) Dalam setiap kegiatan layanan bimbingan konseling hendaknya guru melibatkan siswa secara aktif upaya dalam memecahkan permasalahan yang dihadapi siswa; 4) Guru BK hendaknya mau mencoba untuk mencari teknik atau metode layanan bimbingan konseling yang kreatif, inovatif dan tidak konvensional.

\section{DAFTAR RUJUKAN}

Arikunto, Suharsimi. 2006. Prosedur Penelitian Suatu Pendekatan Praktek, Jakarta: Rineka Cipta.

Aryani. Farida. 2016. Stres Belajar. Makasar: Edukasi Mitra Grafika.

Nurdini, 2009. Stress Pada Siswa Akselerasi. Jurnal Keberbakatan dan Kreativitas. 02.01 Februari. 20-30.

Pramunto, Agus Bambang. 2016. Strategi Relaksasi Untuk Membantu Siswa Yang Mengalami Stres Belajar Di Kelas 9D SMP Negeri 1 Mejayan Kabupaten Madiun, http://ejournal.unipma.ac.id/index.php/JBK/article/download/266/238.

Suyono, Triyono, Dany M. Handarini,. Keefektifan Teknik Relaksasi Untuk Menurunkan Stress Akademik Siswa SMA, Vol. 4 No. 2 Juni 2016 h.117.

Subandi. 2003. Psikoterapi Pendekatan Konvensional dan Kontemporer. Yogyakarta: Pustaka Pelajar offset. 